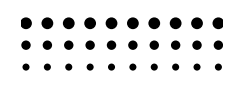

\title{
Introduction
}

Tike a lot of people, I spent very little time contemplatLing the connection between law, criminal justice, and democracy. It wasn't until I had a direct experience of punishment for breaking the law and becoming an advocate for change-ultimately leading a campaign for constitutional reform in Florida-that I was able to thread the needle between all three. Civic, political, and social life in the United States is governed by statutes that most of us seldom consider unless we are directly confronted by their consequences for ourselves and others. Yet I also believe that the infiltration of partisanship in all of these areas threatens the democracy we aspire to have.

As I learned firsthand from my experience with crime and punishment (a story I'll share later in this essay), sometimes the consequences of conviction are far reaching, with implications beyond the specific statute in question. Until recently, 
in my home state of Florida, anyone who was incarcerated for a felony would not only be required to serve time, pay fines, and compensate the victims, but would then face the permanent loss of voting rights. That person could never again participate in elections.

The punitive law that stripped returning citizens-people who are convicted of crimes, serve time, and then resume regular life and activities after paying their debts-of their vote, disenfranchising millions of Floridians over the decades, fundamentally alters the politics of our state and, arguably, the nation. Right now, in the United States of America, over six million people have paid their debts to society for past mistakes, yet they cannot vote.

In 2018, my organization, the Florida Rights Restoration Coalition, led a dark-horse campaign to change the law in Florida by amending our state constitution at the ballot box. This essay will look at why it was necessary, how we overcame partisanship to win a landslide victory, and how its lessons can help save American democracy.

\section{The Impact of Law and Criminal Justice}

The definition of a felony varies widely from state to
state. In Florida, a felony is defined as any crime for which the punishment can exceed a year of imprisonment. Felonies in Florida cover a wide range of illegal behaviors. 
Additionally, the state also has a low threshold for felony conviction when it comes to some crimes. For years, for instance, Florida's felony theft threshold was just \$300much lower than neighboring states like Georgia or South Carolina which classify comparable thefts as misdemeanors. All this means that in Florida felony convictions are comparatively quite common.

In 2010, the last year for which comprehensive data is available, the average national rate of felony conviction was at 8.11 percent of the voting-age population. The rate was almost double that in Florida, at just over 15 percent. Black and Brown Floridians are disproportionately affected in large part because we are more likely to be arrested for drug offenses. And because a felony conviction triggers a loss of civil rights, including the right to vote, one in five Black Floridians were left unable to participate in any election. ${ }^{1}$ The vast majority of these people were not, in fact, behind bars. Like myself, they were returning citizens-people who paid their debts, served their time, and were discharged to resume life in the community. And since our exclusion from voting took away our ability to choose the decision-makers who determine key policies that shape incarceration and reentry, we were also left without the means to address these problems.

Returning citizens face a range of obstacles in reentering communities, including barriers to employment, housing, health care, and basic social services. ${ }^{2}$ For example, 
notwithstanding my contribution to restoring voting rights to returning citizens, the many accolades and awards I received for my leadership, and the material success that accompanies the executive directorship of a major organization, my history of felony conviction still hurts many aspects of my life, just as it does for millions of others who share this experience. I graduated from law school, but am prohibited from taking the Florida bar exam or actually practicing law. I have been named on the "Time 100 Most Influential People" list, but because of the felony on my record, I still can't get approval for a lease. ${ }^{3}$ For returning citizens like me, it's a long and winding road not just to equal rights, but to fairness and redemption. That's why my organization, the Florida Rights Restoration Coalition, ultimately organized returning citizens and their families for the long haul.

Throughout my early advocacy days, I spent a considerable amount of time engaged in "get out the vote" and voter registration efforts. I would often encounter people whose response to my effort would be, "I don't have time to waste on that"; "My vote doesn't count"; or, "Even if I vote, it doesn't matter who gets in office; we're still screwed!" I was always taught to not debate with people when they refuse to engage. My supervisor always told me to keep it moving; primarily because I needed to have a certain amount of engagements on a daily basis. I needed to "make the numbers," or meet the quota. When I first started, I used to adhere to that guidance, but eventually I became too curious to continue to ignore 
these frequent responses. I just had to know what it was that caused people to feel so apathetic about voting; what was making people lose hope in a democracy that was supposed to be for them. So I broke the rule. One day after I was given the typical response, I started to walk away, but I couldn't contain my curiosity any longer. I turned around and asked that person why they held that belief.

Almost immediately after starting the conversion, I discovered that this person couldn't even vote to begin with, having been barred from voting due to a prior felony conviction. This revelation took me back to a time after being released from prison. As I would be walking to some destination or another, someone would approach me and ask if I would like to register to vote, or if I would like to actually go and vote in a current election. These questions triggered an internal feeling of shame. It was a brutal reminder that I was not truly a part of my community; and telling someone about a past felony conviction or imprisonment is a badge of shame that I, like so many others, didn't care to share unless it was really necessary. I understood why someone could so easily respond with indifference. Nothing speaks more to citizenship than being able to vote; therefore, how can one feel like they are a part of society or a part of their community when they are being denied the franchise?

After that eye-opening conversation, I decided to figure out a way to quickly determine if someone's refusal to engage was because they didn't want to be bothered, or whether it 
was because they had been barred from voting. I developed an approach that allowed me, within a matter of seconds, to quickly identify who was the returning citizen. What I discovered was revelatory. The overwhelming number of people upset by my approach were returning citizens. It wasn't that a lot of people I encountered didn't care about participating in our democracy. It was that a lot of people I encountered believed that they could not.

I began to notice this narrative about voting not being important, or "our vote doesn't matter," was a story that was most prevalent among returning citizens. Its purpose was to mask the pain and embarrassment of exclusion. Worse, its effect reached into entire families and communities. The narrative is not exclusive to the encounter between activists and returning citizens. It also appears wherever and whenever there is a discussion about registering to vote or going to vote during an election. As a result, it is not only heard by activists, but also by family members, friends, and colleagues. Indeed, I also discovered that the impact of the loss of voting rights is not restricted to the returning citizen. Families and social networks also carry the burdens. I found that having someone in your life who is barred from voting can influence whether or not you vote, too: if the returning citizen is someone of influence within their circle of friends, family, or community-a not-uncommon situation-then whole groups of people who otherwise would be qualified to vote become uninterested in the process. 
This deadening of voices is tragic. During the civil rights era, family played an important role in voting. When Mom and Dad went to the ballot box, the outing was a household affair. Everyone would get dressed in their "Sunday best" and head to the polling location, kids and all. Voting and civic engagement were a part of the family's dinner table discussions. Children heard early in life about the hard-won right to vote and how that hard work and sacrifice are honored when one votes. But when you strip Mom and Dad of the right to vote; when you use the mechanism of mass incarceration to erode the family structure; and when you utilize statesanctioned tactics to discourage voter participation, those dinner table discussions become the exception rather than the norm. Those family trips to the polling location cease.

\section{Case Background: Felony Disenfranchisement in Florida}

iven the history, scale, and effects of felony disenfran$\mathbf{J}_{\text {chisement in Florida, the stakes of any effort to reverse }}$ the trend were incredibly high to start with. But the implications were compelling for our state and the country as a whole. A quick history of felony incarceration and disenfranchisement illustrates the point.

Despite falling incarceration rates over the last several years, the United States still has the highest rate in the world. ${ }^{4}$ 
It puts more people behind bars every year than any other nation. Moreover, even today in states like Virginia and Kentucky (and as recently as 2018 in Florida and 2020 in Iowa), state-level systems effectively erase these individuals from our democracy by denying them the right to vote. The United States is not the only place where incarcerated people face punitive voting prohibitions, but it is an outlier in its failure to automatically restore those voting rights once a person's sentences are complete and their debts are paid. We are the only postindustrial country where those with felony records can be permanently disenfranchised.

In a nation where more people are convicted and incarcerated for felonies than anywhere in the world, the disenfranchisement of people with felony convictions has tremendous implications for democracy. Florida is ground zero for those implications. It's the nation's biggest and highest-profile "battleground" state, an epicenter of demographic shifts in the voting-age population and home to a litany of razor-thin election victories. And while Florida was not alone in denying incarcerated people their democratic voice, the state has been unique for the sheer volume of its disenfranchised people. Nationwide in 2016, over 4.7 million of the 6.1 million people who were disenfranchised were not incarcerated but also not legally permitted to vote. Before passage of Amendment 4, Florida accounted for nearly 30 percent of that national total. Remember that the majority of disenfranchised people are actually not behind bars, but 
returning citizens like myself. They are out of jail or prison and living in communities where they typically work, pay taxes, abide by the law, and live normally-but for all that, they continue to be excluded from the democratic process and face a host of additional barriers to employment, housing, and resources.

Meanwhile, according to the Prison Policy Institute, Florida's rate of incarceration still exceeds both the US national average and rates in any country. ${ }^{5}$ Today, 176,000 Floridians are locked up in various facilities. Black and Brown people are overrepresented in Florida prisons and jails. Black felons are incarcerated at over three times the rate of White felons; Hispanics at twice the rate. Black Floridians are not the only people affected by voter disenfranchisement, but it is the ethnic group that feels it the most.

These numbers make the disenfranchisement of felons not just a voting-rights issue, but a civil rights battle. And in the case of Florida, that battle stretches back 150 years. The state's first constitution stripped people convicted of felonies of their right to vote permanently, and as the years progressed, that law remained among the most restrictive in the nation. It is well documented that the impetus behind felon disenfranchisement laws in the South rested on the back of racism, and I believe that racism is a real poison to the democracy we aspire to live in. As we would eventually prove in our campaign to reverse some of these injustices, the key to victory was to find a way past racism and connect 
returning citizens as Americans, friends, brothers, pastors, mothers, and colleagues, restoring our democracy from the community upward.

But it would not be an easy argument to make, not at first. To understand why, we have to understand a little bit of history. 